\title{
Capitalismo e educação: novas conformações na passagem para o século XXI
}

Capitalism and education: new configurations before the $21^{\text {st }}$ century

Capitalismo y educación: Nuevas conformaciones de camino al siglo XXI

Capitalisme et éducation : nouvelles configurations au tournant du XXIe siècle

\section{Hiran Roedel e Isa Ferreira Martins}

\section{OpenEdition}

\section{Journals}

\section{Edição electrónica}

URL: http://journals.openedition.org/espacoeconomia/4732

DOI: 10.4000/espacoeconomia.4732

ISSN: 2317-7837

\section{Editora}

Núcleo de Pesquisa Espaço \& Economia

\section{Refêrencia eletrónica}

Hiran Roedel e Isa Ferreira Martins, « Capitalismo e educação: novas conformações na passagem para o século XXI », Espaço e Economia [Online], 13 | 2018, posto online no dia 16 dezembro 2018, consultado o 19 abril 2019. URL : http://journals.openedition.org/espacoeconomia/4732 ; DOI :

10.4000/espacoeconomia.4732

Este documento foi criado de forma automática no dia 19 Abril 2019.

(C) NUPEE 


\title{
Capitalismo e educação: novas conformações na passagem para o século XXI
}

\author{
Capitalism and education: new configurations before the $21^{\text {st }}$ century \\ Capitalismo y educación: Nuevas conformaciones de camino al siglo XXI \\ Capitalisme et éducation : nouvelles configurations au tournant du XXIe siècle
}

Hiran Roedel e Isa Ferreira Martins

\section{Introdução}

2 Este artigo tem como proposta analisar o deslocamento do princípio norteador da educação superior no Brasil na passagem para o século XXI. Partimos do pressuposto de que vivemos uma reordenação e reconfiguração de suas relações manifestadas a partir do estabelecimento da hegemonia capitalista de orientação neoliberal em fins do século passado.

3 Nessa perspectiva, admitimos, de antemão, que o capital exerce o poder de condicionar e estabelecer o conjunto das relações sociais. Ou seja, o poder de condicionar e articular essas relações no âmbito da economia, da cultura, da política e da ideologia se encontra submetidas à lógica do capital. É ele quem as conforma para moldá-las e transformá-las permanentemente.

4 Ao admitir esse princípio de totalidade do capital, podemos aceitar que este interpenetra todas as demais formas de relações, tencionando-as e conformando-as na perspectiva de submetê-las à lógica do valor ${ }^{1}$, dado ser este (o valor) uma forma específica e estruturante do capitalismo. Sendo assim, as mudanças por ele processadas no método de produção, favorecidas pela introdução de novas tecnologias e/ou novas formas de organização, 
geram, por conseguinte, novas demandas que impactam a dinâmica das relações nos demais campos ${ }^{2}$ sociais.

5 Se, por um lado, concebemos que as alterações/mudanças na base estrutural da sociedade impulsionam reações nas demais formas de relações, por outro, não podemos deixar de considerar que as novas conformações da capacidade dirigente, ou seja, do consenso, são estabelecidas a partir do campo ideológico. É ali que se constrói, portanto, a hegemonia, estabelecendo a unidade dialética entre infra e superestrutura.

6 Ao partirmos, todavia, desse entendimento do capital enquanto relação social de produção e de consumo, isto é, articulando as condições de produção estrutural com a subjetividade por ela gerada, podemos apreender a totalidade do processo históricosocial. Por isso, interpelar as transformações vivenciadas em espaços de manipulação e produção de subjetividades possibilita-nos observar as novas conformações das relações que neles se estabelecem.

7 É nesse sentido que o campo da educação ganha centralidade nesse debate. Não somente por sua responsabilidade na formação intelectual dos indivíduos, mas também pela reconfiguração de suas relações a partir do avanço da lógica do valor.

8 Não é, contudo, objetivo realizar uma análise didático-pedagógica do campo educacional, mas sim identificar, neste, elementos de afirmação da expansão do valor. Para tal, privilegiaremos o setor privado do ensino superior por ser este o mais sensível a essas transformações, bem como, enquanto empresas, se constituem em sujeitos de pressão para a expansão das novas configurações de relações sociais.

9 Essa opção decorre do fato de entendermos que está em curso a reconfiguração do papel desempenhado pelo ensino superior no Brasil. Reconfiguração que tem nas transformações vivenciadas nas relações capitalistas, em nível mundial e nacional, seu motor.

10 Entendido dessa forma, torna-se fundamental observar e vincular essas mudanças não pelo foco da gestão dessas empresas, mas de qual o papel, no campo ideológico, que a educação ocupa no processo dessas transformações. Por isso, constitui ponto de partida desta análise a elaboração de um panorama sobre as atuais condições do capitalismo, como forma de permitir a articulação global do processo.

11 Não podemos, por isso mesmo, deixar também de abordar as orientações políticas e ideológicas que veem norteando esse processo de transformação nas relações capitalistas de produção. Esses dois campos comporão a articulação visando estabelecer a unidade dialética entre infra e superestrutura e, desse modo, tendo como objetivo possibilitar ao leitor a visão global.

Contudo, para estabelecermos parâmetros comparativos, se mostra necessário, também, observar quais os princípios que orientaram a organização e implantação da universidade no Brasil. Para isso, apontaremos suas linhas mestras a partir dos anos de 1930, objetivando estipular, justamente, o quadro comparativo.

Iniciaremos nossa discussão sobre o capitalismo no século XX e suas reconfigurações na passagem para o século XXI, pois entendemos ser necessário uma breve caracterização de sua forma dominante de organização ao longo desse século, como pressuposto de identificarmos os pontos de mudanças e os de permanência, no que diz respeito às relações de produção. 


\section{0 capitalismo na passagem para o século $\mathrm{XXI}$}

14 Partiremos da afirmação de que as mudanças vividas nas relações de produção decorrem da busca incessante do regime do capital na ampliação da extração de mais-valor. Ampliação essa que se encontra relacionada ao aumento da produtividade, o que, por extensão, induz à organização de novos métodos de produção (POSTONE, 2014, p. 334).

Acrescenta-se ao foco da interpretação do significado de capital não simplesmente a propriedade material de máquinas, terras, ativos etc. Incluem-se, também, as relações de produção e suas implicações sociais. Ou seja, tal qual observou Marx, quando afirmava que

[...] a propriedade de dinheiro, de meios de subsistência, de máquinas e de outros meios de produção não transforma um homem em capitalista, se lhe falta o complemento, o trabalhador assalariado, o outro homem que é forçado a vender-se a si mesmo voluntariamente. Descobriu que o capital não é uma coisa, mas uma relação social entre pessoas, efetivada através de coisas.(MARX, 1980, p. 885)

16 Nesse sentido, observar o aumento da produtividade e a indução de novos métodos de produção vivenciados ao longo do século XX implica em entender, como premissa, que nesse século o capitalismo desenvolveu extraordinárias condições de extração de maisvalor. Isto é, manteve a centralidade de mediação do trabalho na sociedade capitalista como produtor de valor, obtido a partir do dispêndio de tempo de trabalho abstrato (BOTTOMORE, 1988, p. 383) ${ }^{3}$, ao mesmo tempo em que o capital assumia a condição de totalidade social, definindo também as condições subjetivas.

17 Ao se observar, portanto, que a extração de mais-valor é central para o regime do capital, a forma de sua extração ganha relevância. Nesse sentido, não se pode deixar de destacar os dois principais métodos de produção que dominaram o capitalismo em sua fase de maior expansão.

18 Assim, na busca por melhor racionalização da extração de mais-valor, é que o taylorismo e o fordismo se consolidam, na primeira metade do século XX, como métodos de produção. Se o primeiro tem como princípio norteador a intensificação do trabalho em menor tempo possível, bem como a fragmentação do processo produtivo, o fordismo o estende desenvolvendo à linha de montagem. Intensifica-se e aperfeiçoa a extração de mais-valor, tendo em vista que a condição do tempo do trabalho é ditado pelo ritmo da máquina que impõe ao trabalhador o aumento de sua produtividade(MARX, 1978, p. 466).

19 E mais ainda! Não podemos deixar de observar que o avanço das relações capitalistas igualmente trazem consigo o fato de que a

Produção mecânica tem consequências extremamente negativas: o trabalho se torna ainda mais fragmentado, mulheres e crianças são empregadas em funções repetitivas e mal remuneradas, cai o nível intelectual do trabalho e ou há ampliação da jornada ou aumento da intensidade de trabalho. Além disso, os efeitos negativos não se restringem ao local da produção imediata: esse modo de produção prejudica a segurança dos trabalhadores e acarreta a criação de uma população trabalhadora descartável, deixada como reserva para as necessidades da exploração capitalista. Ele afeta negativamente a saúde, o nível geral das capacidades intelectuais e sensibilidades morais e a vida familiar da população trabalhadora (POSTONE,2014, p. 394). 

nacional se constitui em ferramenta fundamental de acumulação capitalista. Sendo assim, as relações comerciais que ali se formavam encontravam-se regidas pelo poder dos oligopólios, cujas matrizes sempre se localizavam nos países centrais. Nessa perspectiva, a divisão internacional do trabalho gerava e perpetuava a condição de dependência, ao 
mesmo tempo em que condicionava e amarrava as economias periféricas aos percalços das economias centrais. Ou seja, a condição de dependência tem de ser vista como um condicionante histórico do próprio modelo de desenvolvimento do capitalismo mundial e não como uma etapa a ser superada (SANTOS, 2015, p.18).

Diante dessa articulação entre o nacional e o internacional, não nos espanta que a crise do petróleo nos anos 70, o aumento da competição internacional, a diminuição das margens de lucro e o aumento do desemprego levassem o fordismo a ser posto em xeque em escala mundial. E como resposta, nessa conjuntura e diante da pressão do movimento sindical, o capital reorienta seu método de produção adotando regimes de trabalho mais flexíveis e, por conseguinte, reestruturando as formas e relações econômicas internacionais.

reestruturação do processo de acumulação implicou, por sua vez, na orientação voltada para a expansão financeira. Expansão em que "uma massa crescente de capital é revertida para sua forma monetária e ruma para empréstimos e especulação" (GIOVANNI, 1997, p.355), conectando, privilegiadamente, as economias centrais através do sistema financeiro que já se mundializava.

31 As mudanças estruturais na sociedade brasileira que permitiriam o avanço do capital ganham corpo de projeto nacional a partir da década de 1930. Não é de outra maneira senão pelo intervencionismo estatal que se criam as condições fundamentais para fazer progredir, no país, as relações capitalistas de produção ao se lançar as bases da indústria pesada. Organizavam-se, desse modo, as condições econômicas e políticas para se construir a hegemonia burguesa no Brasil.

Por isso que o método de produção fordista, ao se expandir pelo mundo no pós $2^{\mathrm{a}}$ Guerra Mundial, encontra o Brasil já dotado das condições para a expansão industrial. É nessa conjuntura, e dando continuidade ao processo de transformações estruturais intensificadas no pós-30, que o fordismo chega na década de 1950, ao país, com a substituição de importações e a implantação da linha de montagem automobilística, constituindo-se, por conseguinte, no padrão de desenvolvimento industrial.

Com a importação de capitais oriundos especialmente dos EUA, afirmava-se, assim, a lógica de um desenvolvimento capitalista dependente. Ou seja, a expansão do capitalismo impulsionador da industrialização confirmava o estado de subdesenvolvimento como condição de inserção do país no mercado mundial.

Desse modo, ao conciliar os processos de acumulação do atraso de tipo colonial no campo, onde predominam a grande propriedade e relações de produção arcaicas, com o avanço da industrialização orientada pelo fordismo, as relações capitalistas se expandem gradativamente no país. Contudo, esse processo gerou o aprofundamento das contradições ao acelerar o êxodo rural. Aliado a isso, conta-se com a incapacidade do bloco de classes economicamente dominantes em responder às demandas sociais das grandes massas de trabalhadores. Ou seja, diante dessa incapacidade de incluí-las nas benesses do crescimento econômico, a resposta à pressão das massas foi o fechamento político com o golpe de 1964 .

Isto é, diferentemente da matriz geográfica do fordismo, o caminho brasileiro não incluiu os sindicatos e trabalhadores como "parceiros". Estes foram silenciados por duas décadas para que a expansão industrial ganhasse fôlego, ao mesmo tempo em que o sistema financeiro também se estruturasse em âmbito nacional. Pois, afinal, a inexistência de uma burguesia nacional não punha em contradição a classe dominante economicamente para 
com o imperialismo. Sua proposta de mudança sempre adotou o modelo de revolução passiva ${ }^{4}$, transformista e gradual, cuja contradição fundamental não se encontraria em relação ao capital internacional, mas sim em relação à classe trabalhadora interna.

Mas a crise vivida pelo capitalismo nos anos 70 colocou o modelo brasileiro também em crise. A pressão dos trabalhadores, mais o fracionamento do bloco de classes dominante levaram ao aprofundamento da perda de apoio político a esse modelo.

Nas décadas seguintes, a estrutura econômica sofreu ajustes de modo a se adequar à reestruturação neoliberal do processo de acumulação imposto pelas economias centrais. Se no desmonte do regime político ditatorial a sociedade civil e, em especial os sindicatos, tiveram papel importante, por outro lado a reestruturação capitalista impacta estes últimos significativamente. Seu esvaziamento político reflete em seu poder de mobilização ${ }^{5}$ que se vê comprometido frente a um trabalhador capturado pela visão de mundo do capital que se considera, ele mesmo em seus investimentos de formação, como capital humano. Por extensão, as relações de solidariedade de classe gradativamente se esgarçam, enquanto também se esmaece a capacidade de formulação de projetos futuros de sociedade e de nação.

Nesse contexto, cabe a indagação de qual o papel desempenhado pelo campo da educação no avanço das relações capitalistas na sociedade brasileira?

Para tal, consideramos, conforme observa Gramsci,

que, em geral, na civilização moderna, todas as atividades práticas se tornaram tão complexas, e as ciências se mesclaram de tal modo à vida, que toda atividade prática tende a criar uma escola para os próprios dirigentes e especialistas e, consequentemente, tende a criar um grupo de intelectuais especialistas de nível mais elevado que ensinam nestas escolas. (GRAMSCI,1995, p. 117).

Consideramos, então, que a educação participa de forma privilegiada, enquanto aparelho de hegemonia, na formação da concepção de mundo ${ }^{6}$ dos indivíduos. Se aceitamos essa tese, podemos partir do entendimento de seu aspecto não simplesmente políticoeducacional, mas marcadamente ideológico.

41 Constitui, portanto, necessidade, para evitar ambiguidades de entendimento, algumas rápidas considerações a respeito do entendimento de ideologia.

\section{Considerações a respeito do campo ideológico}

De acordo com Marx, os conflitos gerados pelas transformações vividas na estrutura econômica levam os indivíduos a se confrontarem com eles no plano ideológico. E é aí que os indivíduos ganham consciência dos conflitos para, então, buscarem resolvê-los (MARX, https://www.marxists.org/portugues/marx/1859/01/prefacio.htm. Acesso em outubro de 2017). E Lukács chama a atenção para o fato de que esses são "conflitos que emergem dos fundamentos do ser social" (LUKÁCS, 2010. p. 38).

Partimos do entendimento, com isso, de que a ideologia tem o campo social como produção e condição para a sua realização. Por isso que para Gramsci "é na ideologia e pela ideologia que uma classe pode exercer hegemonia sobre outras, isto é, pode assegurar a adesão e o consentimento das grandes massas" (BOTTOMORE, 2013, p.186). Pois:

É graças à ideologia que um sujeito coletivo torna-se consciente de si e, portanto, pode contrapor-se à hegemonia adversária: a ideologia como lugar de constituição 
da subjetividade coletiva. Se não se entende que este sujeito - que se tornou consciente de si - deve munir-se de um próprio "aparelho hegemônico" (ideológico) para travar sua luta nas concretas "fortalezas e casamatas" do Estado “integral”, permanecer-se-á preso a uma concepção idealista e ao mesmo tempo racionalista-iluminista. (Dicionário Gramsciano, 2017 p. 400).

Mas, avançando na reflexão, podemos também entender que a ideologia é uma falsa consciência, não como alguns apregoam, e sim porque as verdadeiras forças propulsoras desse processo permanecem ignoradas por seus sujeitos (SILVA, 2013, p. 58). Sendo assim, ela é, desse modo, conforme destaca Mészáros, "uma forma específica de consciência social, materialmente ancorada e sustentada" (MÉSZÁROS, 2004, p.65).

endermos dessa forma a noção de ideologia, podemos identificar os interesses de classe a ela correspondente. Mais ainda! Possibilita compreender a necessidade de se travar a luta de classes no plano das ideias, bem como, a partir de então, formular um conjunto de soluções próprias de classe em relação aos conflitos existentes no campo social e, assim, construir a hegemonia.

6 Diante disso, a forma de se perceber as contradições existentes na estrutura econômica, ao se encontrar vinculada à ideologia, constrói a subjetividade coletiva que orienta a sua solução. Aí se encontra a importância dos aparelhos de hegemonia, nos quais as instituições educacionais se inserem. E é por isso, de acordo com essa concepção, que a organização da educação sempre se encontra articulado ao projeto político da classe hegemônica.

Com o avanço das relações capitalistas de produção no Brasil, um novo projeto nacional e societário se faz necessário, a partir dos anos 30 , no momento em que a burguesia urbana (industrial e comercial) assume a condição de classe economicamente dominante e, por conseguinte, protagonista política. Por isso, trabalharemos com a concepção de ideologia da forma como esboçamos acima.

\section{O campo da educação superior}

4 Partimos do entendimento de que o processo de transição para o predomínio do capital industrial se dá, de forma mais evidente, na passagem da década de 1920 para a de 1930. Nessa conjuntura, ganham projeção no Brasil as relações de produção capitalistas, bem como o espaço urbano, especialmente na região sudeste, que gradativamente passa a se configurar, geograficamente, no centro dinâmico da nova estrutura econômica do país.

No bojo do avanço das relações capitalistas, além do crescimento do operariado urbano, também se percebe a expansão da classe média. Ou seja, emergem novos sujeitos sociais e políticos que reconfiguram o quadro das contradições/tensões alterando, com isso, a capacidade de hegemonia da classe latifundiária.

Assume relevância, cada vez mais, nesse momento, o debate sobre os novos parâmetros societários e de nação. Não é por outro motivo que, a partir de meados da década de 1930, a centralização e controle dos aparelhos de hegemonia por parte do Estado tendeu a se constituir como regra, apesar da oposição de grupos de intelectuais ${ }^{7}$ (MENDONÇA, p. 131-194, no 14, 2000). Era, afinal, necessário a organização de um novo consenso cujo campo da educação assume papel de destaque. Pois, a "escola - em todos os seus níveis - e a Igreja são as duas maiores organizações culturais em todos os países, graças ao número de pessoas que utilizam." (GRAMSCI, 2004, p.112). 
51 Os diversos grupos de intelectuais, independente da matriz ideológico, por sua vez, compartilhavam do ideário de assumirem, eles, enquanto elite detentora do saber científico, a condição exclusiva de se pensar a nação. Apesar da pretensão dos intelectuais,

[...] há uma intenção explícita do governo federal, principalmente após 37, de assumir o controle das iniciativas no campo cultural. A ideia comum aos projetos da USP e da UDF, de formar na universidade as elites que, com base na autoridade do saber, iriam orientar a nação (colocando-se, de certa forma, acima do Estado), seria, no contexto do Estado Novo, considerada perigosa. Ao governo federal interessava ter o monopólio de formação dessas elites e por isso impunha sua tutela sobre a universidade (MENDONÇA, 2000, p.140).

52 A vinculação da organização e expansão da universidade no Brasil ao projeto de sociedade se constitui, portanto, em uma necessidade das transformações estruturais que se processavam. Por isso que, nesse contexto, conforme se ampliava o espaço político dos intelectuais, estes se autoatribuiam o papel de, por serem possuidores do saber, condutores dos rumos da nação.

53 Mas a educação em geral e a universidade em especial, fica evidente, assumem posição estratégica no projeto de nação. Com a nova configuração socioeconômica, ganham destaque e se expandem "novas oportunidades de acesso ao ensino superior e de carreira no magistério [que] ajudaram a criar uma demanda que foi amplamente explorada pelas novas classes médias urbanas em formação" (SAMPAIO, 1991, p.13).

É nessa conjuntura que se abre espaço, também, para o setor privado religioso. No bojo dessas oportunidades e seguindo o processo de distanciamento entre Estado e Igreja, surge, em 1941, a Universidade Pontifícia Católica no Rio de Janeiro.

Porém, apesar da ampliação de oportunidade de acesso ao ensino superior, este mantinha-se como privilegiado de parte de pequenos núcleos de representantes das classes economicamente dominantes, o que denuncia a visão de classe sobre a realidade (Cf. LIPPI, 1980) dessa dita elite intelectual. Por isso e nessa perspectiva, é importante destacar que o perfil do conhecimento científico. Este age ideologicamente fornecendo certezas sobre a interpretação do real e, assim, atuando como poder (ZIZEK, 2014. p.74.), e, nesse caso, perpetuando a hierarquia social vigente. E, dessa forma, é

[...] mantida a dupla articulação, a alta burguesia, a burguesia e a pequenaburguesia "fazem história". Mas fazem uma história de circuito fechado ou, em outras palavras, a história que começa e termina no capitalismo competitivo dependente. Este não pode romper consigo mesmo. Como a dominação burguesa, sob a sua vigência, não pode romper com ele, a economia capitalista competitiva da periferia fica condenada a dar novos saltos através de impulsos que virão de fora, dos dinamismos das economias capitalistas centrais (FERNANDES, 1976. p. 250).

56 Esse contexto explica, pelo menos em parte, o fato da universidade brasileira ter sido criada no modelo de cátedra ${ }^{8}$, expressando uma herança oligárquica. Mesmo que logo nos anos 50, com o desenvolvimentismo, a substituição de importações e a chegada do fordismo no país, a universidade inicie sua modernização, se aproximando do modelo norte-americano. A adoção gradativa do sistema de departamentos teria sua afirmação em fins dos anos 60, com a reforma de 1968, o que definiria o modelo de universidade e os parâmetros da carreira universitária.

57 Cabe ressaltar, contudo, que a universidade, sob a égide do desenvolvimentismo que predominou nos anos 50, não se afastou das exigências socioeconômicas que pautaram sua formação, mesmo quando de sua modernização. Ou seja, ela não se distancia do 
projeto de nação, e muito pelo contrário, se afirma como um de seus pilares, o que se estende, inclusive, ao longo do regime pós-64.

Podemos observar essa vinculação, por exemplo, a partir da expansão do número de matrículas no ensino superior no período de 20 anos, entre 1940-1960. Constata-se um crescimento de mais de três vezes, quando salta de 27.671 para 93.202. Ao se comparar com o crescimento da população, esta passou de 41 para 70 milhões, perfazendo um crescimento de $70 \%$. Já no setor privado, entre 1954-1960, as matrículas cresceram 44\%, saltando de 25.905 para 41.287 (SAMPAIO,1991, p. 16).

Estava posto, no entanto, uma dualidade no modelo universitário. Apesar de seguir o padrão norte-americano de departamentos, este foi implantado sob forte controle estatal dentro de um projeto de Brasil potência, portanto fora dos parâmetros liberais. E é nesse contexto que se abriu, ao mesmo tempo, espaço para empresas de educação com fins lucrativos se expandirem devido à crescente demanda por diploma de ensino superior existente no mercado. Assim, em vinte anos "o número de matrículas no ensino superior vai de 93.902 (1960) para 1.345.000 (1980), sendo os anos de 1968, 1970 e 1971 os que apresentam as maiores taxas de crescimento" (SAMPAIO,1991, p. 17).

Podemos observar, desse modo, que o regime pós-64 dedica especial atenção ao ensino superior. Contudo, não se pode inferir dessa atenção do regime a preocupação em criar as bases de um capitalismo independente. Pois, a despeito da expansão do acesso à educação superior, atentemos para o fato de que se "em 1960 as matrículas em instituições privadas representavam $44,3 \%$ sobre o total de matrículas no ensino superior, em 1980, elas passam a representar $63,3 \%$ (852.000) [...], o que corrobora a tese de que o aumento do estudantado de $3^{\circ}$ grau se deu acima de tudo pela expansão do setor privado" (SAMPAIO,1991, p. 18), o que já conota a ingerência da lógica do valor no campo da educação superior em um capitalismo dependente.

Mas o clima político dos anos 80 expressa a alteração na correlação de forças políticas. 0 recuo das frações sociopolíticas ditatoriais que controlavam o aparelho burocrático do Estado no pós-64, diante da mobilização e articulação da sociedade civil e a aliança entre as concepções liberais e de esquerda mais a mobilização popular apontavam para uma nova conjuntura.

Com a queda do regime ditatorial, em 1985, observa-se a rearticulação das forças políticas no país. Enquanto nos EUA, com Ronald Reagan, e na Inglaterra, com Margaret Thatcher, estruturam-se as bases do neoliberalismo, cujo Chile se constituiu em seu principal laboratório, no Brasil se encaminhava para a organização de um novo projeto de nação em que a pressão da sociedade civil empunhava um forte apelo de cunho social, culminando na Constituição de 1988. Apesar disso, entretanto, a conjuntura da segunda metade dos anos 80, no Brasil, foi a antessala do neoliberalismo da década seguinte.

\section{Neoliberalismo: rápidas considerações}

63 A ideologia do neoliberalismo ganha enorme força a partir da queda do muro de Berlim e do desmonte das experiências socialistas do Leste europeu e asiático. Assim, o seu avanço rumo à condição de exercer a hegemonia na forma de organização do capital se deu ao longo da década de 1990, quando este se afirma como a expressão da força burguesa de um mundo não mais bipolarizado. 

na economia. direta de mercadorias.
É nesse momento que alguns de seus princípios passam a caracterizar a nova condição do capitalismo. Dentre esses, tornaram-se lugar-comum a defesa às privatizações de empresas estatais, abertura da economia aos monopólios internacionais, diminuição do Estado, flexibilização das leis trabalhistas, terceirização e a "não" intervenção do Estado

Concomitantes ao neoliberalismo que se afirmava no campo das políticas econômicas, observava-se a implantação de formas flexíveis de organização associadas aos investimentos em novas tecnologias (automação e robótica), implicando na redução drástica do número de trabalhadores na produção e expansão do mais-valor. Ou seja, acelera-se, gradativamente, o distanciamento do trabalho vivo (trabalhador) da produção

Observa-se, nessa mesma conjuntura, o reforço ao capital financeiro. Estratégia utilizada para o rápido deslocamento de investimentos, já que este é a forma mais móvel de capital, para regiões onde a mão de obra tivesse um menor custo, decorrente da flexibilização das leis trabalhistas (HARVEY, outraspalavras.net/capa/neoliberalismo-projeto-politico. Acesso em outubro de 2017).

O Brasil não ficou fora do roteiro neoliberal. A partir dos anos 90, a implantação de seu receituário fez agravar a concentração de renda, o desemprego e a pobreza, o que permitiu que chegássemos, na segunda década do século XXI, a apenas 6 bilionários do país concentrando uma riqueza correspondente à riqueza da metade da população mais pobre do país, ou seja, de mais de 100 milhões de habitantes. Um padrão de concentração não muito diferente do que ocorre em escala global (https://www.unas.org.br/singlepost/2017/01/19/Desigualdade-no-Brasil. Acesso em outubro de 2017).

Desse modo, ao neoliberalismo soma-se à redução da participação direta do trabalho na produção de valor (mercadoria), ao aumento dos desempregados, à crescente pobreza e à horizontalização do método de produzir. Essas são condições que deslocam o trabalho direto da produção e ampliam, para fora de seu espaço, o conflito de classes. Por isso, cada vez mais a tensão e contradições de classe têm se posicionado na vida da cidade, na circulação, onde o valor efetivamente se realiza. Pois, como bem ressalta David Harvey,

O valor é produzido no processo do trabalho, e é um aspecto muito importante da luta de classes. Mas o valor se realiza no mercado através da venda, e uma boa parte da política tem aí seu lugar. Uma grande parte da resistência à acumulação do capital se exprime não somente no lugar de produção, mas também através do consumo, na esfera da realização do valor. (HARVEY, outraspalavras.net/capa/ neoliberalismo-projeto-politico/)

Outro aspecto que não podemos deixar de considerar, é a livre circulação de capitais no mercado internacional que, para o neoliberalismo, deveria ser levado às últimas consequências com a eliminação de leis de proteção às economias nacionais, além, é óbvio, das privatizações. Esse movimento difunde a ideia de que o mercado entre as nações não seria mais, com o fim da Guerra Fria, hierarquizado, mas sim horizontalizado, o que se convencionou chamar de globalização.

O conceito de globalização passou, a partir dos anos 90, a se constituir em um consenso contaminando, com sua lógica comercial, todos os campos da vida social. Nesse sentido, o conceito de capital humano penetra com força na formação intelectual. Ou seja, esta passa a ser entendida como o resultado das exigências de competências impostas como condição pelo mercado de trabalho. 
71 É posto ao trabalhador, portanto, a determinação de se adaptar às demandas empresariais. E nessas demandas encontram-se o conhecimento concebido como capital e, derivando daí, o conceito do capital humano. Neste, a qualidade dos serviços são entendidos como vinculadas aos investimentos individuais do empregado em sua formação.

72 Sendo assim e de acordo com a teoria do capital humano defendido pela ideologia neoliberal, os custos dessa qualificação competem aos empregados. Pois, como entendem os neoliberais: "Os trabalhadores tornaram-se capitalistas não em consequência da propriedade de ações das corporações, como o folklore o considerou, mas em virtude da aquisição de conhecimentos e capacidades que possuíam valor econômico"(SAUL, 230-273, p. 258, 2004).

Esse entendimento impacta diretamente o mercado de trabalho ao reforçar, não só a hierarquia salarial, mas a própria desigualdade social quando joga para o indivíduo a responsabilidade de sua formação. Por isso, e não é à toa, que ao se observar o avanço da lógica do valor percebemos que este passa a atuar de forma cada vez mais evidente como força estruturante também do campo da educação, tendo em vista ser este um importante campo na formação da concepção de mundo hegemônico.

74 Pudemos observar assim, em linhas gerais, as implicações das políticas neoliberais para a sociedade como um todo. Porém, se o neoliberalismo atua na lógica da reestruturação produtiva do regime do capital, a forma mais expressiva de tradução dos interesses ideológicos da classe burguesa nessa conjuntura é, por sua vez, o discurso da pósmodernidade. Diante disso, torna-se necessário uma rápida, e também geral, abordagem sobre esse ponto.

\section{Pós-modernidade}

Retomemos a observação de Marx de que o capital é uma relação social entre pessoas. Partindo desse pressuposto, a sociedade dominada por ele não se define somente por sua estrutura econômica, mas esta também produz, além de mercadorias, gostos, desejos, comportamentos etc.. Ou seja, gera e organiza uma subjetividade própria de suas condições de dominação.

No Manifesto Comunista, Marx apontou que a sociedade burguesa tende a um processo de transformação permanente. Como afirmação de sua época, “A burguesia rasgou o véu de sentimentalismo que envolvia as relações de família e reduziu-as a simples relações monetárias". E prossegue:

A burguesia só pode existir com a condição de revolucionar incessantemente os instrumentos de produção, por conseguinte, as relações de produção e, com isso, todas as relações sociais [...] Dissolvem-se todas as relações sociais antigas e cristalizadas, com seu cortejo de concepções e de ideias secularmente veneradas; as relações que as substituem tornam-se antiquadas antes de se ossificar. Tudo que era sólido e estável se volatiza, tudo o que era sagrado é profanado...(MARX, 1996, p.69).

77 É, portanto, característica da modernidade sua permanente transformação, porém é no processo histórico que, ao estabelecer a ligação com o tempo passado, nos permite a sensação da experiência vivida. E é esse sentido de trajetória no tempo que possibilita que se afirmem as identidades de classe e de nacionalidade, por exemplo. 

intensa mudança tecnológica no âmbito da estrutura econômica, alteraram a relação com o tempo e, por isso, também a noção deste. Isso decorre não de forma estranha à sociedade burguesa, mas de acordo com seus princípios norteadores de que esta "só pode existir com a condição de revolucionar incessantemente os instrumentos de produção, por conseguinte, as relações de produção e, com isso, todas as relações sociais".

A consequência dessa revolução, segundo Jamenson, foi que

o desaparecimento do sentido da história, o modo pelo qual o sistema social contemporâneo como um todo demonstra que começou, pouco a pouco, a perder a sua capacidade de preservar o próprio passado e começou a viver em um presente perpétuo, em uma perpétua mudança que apaga aquelas tradições que as formações sociais anteriores, de uma maneira ou de outra, tiveram de preservar (JAMENSON, 16-26, 1985, p.26).

Nesse sentido, a "identidade torna-se uma 'celebração móvel': formada e transformada continuamente em relação às formas pelas quais somos representados ou interpelados nos sistemas culturais que nos rodeiam" (HALL, 2004, p.13). Tendo em vista que as mudanças estruturais impactaram, também, os sistemas culturais a partir do momento que alteraram a relação com o tempo, essas mudanças desestruturaram, igualmente, a noção de identidade individual, de classe e nacional, abrindo espaço para outras formas de interpelações. Com isso, fica fragilizada a antiga solidariedade de classe sustentada por sua relação construída no processo histórico.

81 A instantaneidade passa a constituir a forma de pensar e agir. Instantaneidade e volatilidade passam a ser a principal marca desse novo tempo, o que "torna extremamente difícil qualquer planejamento de longo prazo" (HARVEY, 2005, p.259), não somente em termos econômicos, mas também em termos políticos e pessoais.

Podemos concluir, portanto, que as transformações vivenciadas na sociedade capitalista que desembocaram na considerada pós-modernidade não representam superação da dominação burguesa, mas sim sua afirmação. Ou seja, a compressão do tempo destrói a ideia de processo. $\mathrm{E}$, ao assim proceder, esgarça a noção de identidade de classe e também de nação, pois rompe com seu processo constitutivo e se afirma no presente perpétuo. Dessa forma, o pós-moderno não é outra coisa senão uma forma mais sofisticada e complexa da dominação burguesa em que a individualização assume a maneira de comportamento predominante, na atualidade, em detrimento da coletividade.

\section{O Campo da Educação: os impactos do neoliberalismo e da pós-modernidade}

83 Observemos, mais de perto, a forma como o neoliberalismo e a pós-modernidade impactaram o campo da educação. Ou melhor, de que modo essas ideologias exercem as conformações de suas relações, bem como têm moldado-as e transformado-as.

Comecemos por admitir que a lógica do valor penetrou todos os campos da vida social a partir do fim do século XX. Sendo isso verdade, consideremos, segundo esse entendimento, de que o capitalismo hoje assumiu a condição de hegemonia e, portanto, tem a capacidade de reconfigurar e submeter todas as relações sociais.

Dito isso, entendemos que o campo da educação não se encontra fora dessa influência, mas muito pelo contrário! Pois, se este permanece sendo um importante campo de 
organização da cultura, como apregoava Gramsci, o exercício da hegemonia, a construção e afirmação de uma concepção de mundo, passa invariavelmente pela educação como possibilidade para se construir o consenso. Afinal, não é a ideologia "o lugar de constituição da subjetividade coletiva"?

Localizando o conceito de capital humano a partir da lógica das sociedades industriais avançadas, identificamos que esse interage com outro conceito, o de economia do conhecimento. Isto não significa que sejam similares, mas que ambos partem do pressuposto de que o conhecimento se constituiu em valor. Uma interpretação é que,

[...] a riqueza das sociedades industriais avançadas passam a ser determinadas por uma "teoria do valor do conhecimento", uma vez que o conhecimento teórico servia a dois propósitos principais: sua aplicação por meio do processo de Pesquisa e Desenvolvimento - P\&D - consistia na principal fonte de inovação e ele era essencial para a formulação de políticas de auxílio ao planejamento.(GUILE, 611-636, 2008, p. 613).

No que concerne à economia do conhecimento, esta diz respeito, especialmente, ao papel da ciência para o processo produtivo. Nesse sentido, o que se afirma é que a mesma teria ocupado papel central no capitalismo avançado e possibilitado as novas configurações das relações de produção. E, nesse processo, pode-se observar que teria havido um deslocamento da produção do conhecimento das universidades e laboratórios para dentro das empresas (GUILE, 611-636, 2008, p.616).

Assim, de acordo com a ideologia neoliberal, podemos estabelecer a seguinte inferência: o conhecimento científico estaria para as empresas assim como o capital humano estaria para o trabalhador. Ou seja, tal qual para as empresas, para um trabalhador se mostrar competitivo no mercado de trabalho ele necessita ser detentor de conhecimento que o diferencie e lhe dê vantagem sobre os demais.

Observamos, diante disso, que os trabalhadores são postos na mesma condição que empresas. São, portanto, coisificados. São submetidos à lógica da competição. E esta é permanente; ela se constitui em um "presente perpétuo", o que torna a solidariedade e a identidade de classe uma "celebração móvel" e, por isso, fluida. E mais grave ainda, "o trabalho se torna mais fragmentado [...] cai o nível intelectual do trabalho e [...] acarreta a criação de uma população trabalhadora descartável, deixada como reserva para as necessidades da exploração capitalista" (POSTONE, 2014, p. 394).

Desse modo, em uma economia do conhecimento, o capital humano assume papel de destaque e ganha, também, a arena da educação. Foi nessa perspectiva que o trabalhista e ministro da educação do Reino Unido entre 1997/2001, David Blunkett, defendeu que: "Aprender é a resposta para a prosperidade - para cada um de nós individualmente e para a nação como um todo. Os investimentos no capital humano serão a base para o sucesso na economia global baseada no conhecimento do século XXI" (GUILE, 611-636, 2008, p.630).

91 Dessa forma, produzem-se "teorias e/ou ideologias desenvolvimentistas dentro das quais a teoria do capital humano é uma especificidade do campo educacional" (FRIGOTTO, 2010, p.51). Conforme Frigotto:

O conceito de capital humano - ou, mais extensivamente, de recursos humanos busca traduzir o montante de investimento que uma nação faz ou os indivíduos fazem, na expectativa de retornos adicionais futuros. Do ponto de vista macroeconômico, o investimento no "fator humano" passa a significar um dos determinantes básicos para aumento da produtividade e elemento de superação de atraso econômico. Do ponto de vista microeconômico, constitui-se no fator 
explicativo das diferenças individuais de produtividade e de renda e, consequentemente, de mobilidade social. (FRIGOTTO, 2010, p.51).

Por essa perspectiva, podemos perceber tal teoria no campo da educação quando nos deparamos com discursos e políticas que a vinculam "ao desenvolvimento econômico, à distribuição de renda, configurando-se como uma 'teoria de desenvolvimento"'(FRIGOTTO, 2010, p.51). Vale ressaltar, que essa lógica está presente não só nos documentos do Banco Mundial, mas também em vários outros produzidos por diversas instituições. Dessa forma, circulam discursos nos quais "infere-se literalmente que a educação é um eficiente instrumento de distribuição de renda e equalização social" (FRIGOTTO, 2010, p.55), escamoteando as questões de diferença de classes que não mudam unicamente pela escolaridade.

Nessa perspectiva, o ensino superior ganha nova importância. Não como antes era entendido enquanto legado civilizatório que deveria ser apropriado pelas gerações. Agora, o ensino ganha contornos de mercado. Está capturado, definitivamente, pela lógica do valor. Ou seja, as mudanças de paradigmas econômicos que desembocam, em fins dos anos de 1980 e início dos anos de 1990, no conceito de globalização, sustentado ideologicamente pelo neoliberalismo, ao afirmar a condição de hegemonia do capitalismo, desloca a educação para o campo do negócio.

Essa condição se manifesta, de maneira concreta, a partir de alguns movimentos, em âmbito mundial, em fins dos anos de 1980.

Em termos educacionais o período ao redor das décadas de 1980 e 1990 é marcado pela eclosão de um movimento de reformas educacionais por todo o mundo, instaurando aquilo que Hargreaves e outros (2002) denominam de 'nova ortodoxia oficial', um movimento que é caracterizado pela padronização em torno de políticas de avaliação, de financiamento, de formação de professores e de currículo, num processo de nítida sintonia entre tais políticas e a visão de desenvolvimento preconizada por grandes organismos financeiros internacionais como, por exemplo, o Banco Mundial (WIELEWICKI/OLIVEIRA, 215-234, v. 18, 2010. p.224).

5 Nessa linha, a Europa lançou a Declaração de Bolonha (1999), que, ao considerar a educação superior como uma commodity, a entende como um bem e não mais como direito. Eram as bases para sua efetivação uma década depois com a criação, em 2010, do Espaço Europeu de Educação Superior (EEES), objetivando a padronização da educação superior no continente.

Do outro lado do oceano Atlântico, no continente americano, podemos destacar três grandes investidas do capital que consagraram o caminho para a internacionalização da educação superior. De acordo com Aguilar, são eles: o Tratado de Livre Comércio entre EUA e Canadá, em 1989; o Tratado de Livre Comércio da América do Norte - EUA, Canadá e México -, em 1994; o Acordo de Livre Comércio entre EUA e Chile, em 2003 (AGUILAR, 2007).

7 Esses acordos abriram espaço para a privatização e a descaracterização da educação enquanto direito, transformando-a em serviço e permitindo a formação de consórcios internacionais de universidades. A partir dos anos de 1990, toda a região passou a se constituir em um "mercado" atrativo aos investimentos de instituições estrangeiras de educação superior, especialmente as oriundas dos EUA e da Europa, repercutindo rapidamente no aumento do número dessas instituições (SEGRERA, 2008, http:// dx.doi.org/10.1590/S1414-40772008000200003.. Acessado em 18/11/2015). 
O modelo universitário norte-americano, denominado de capitalismo acadêmico, se constitui, assim, na matriz ideológica e organizativa desses acordos. A aproximação e vinculação das atividades acadêmicas às demandas empresariais, subordinando currículos e a organização das instituições universitárias, passam a definir o modelo de produção acadêmica (SERAFIM, 241-265, 2011), configurando-se na tônica que marcou o campo da educação superior na América Latina.

Seguindo essa orientação, no âmbito do MERCOSUL, em 2000, foi assinado o Compromisso de Gramado que definiu o Plano de Ação do Setor Educativo do bloco para o período de 2001-2005. O objetivo era criar um espaço educativo comum.

Precedeu, porém, a essa iniciativa, algumas incursões, na década de 1990, no que diz respeito às políticas para a educação superior nas duas principais economias do bloco: Brasil e Argentina que, em 1995, criaram leis para adequar a educação superior à tendência de internacionalização. Na Argentina, foi a assinatura da Lei de Educação Superior que instituiu a Comissão Nacional de Avaliação e Acreditação Universitária, enquanto que no Brasil passou-se a adotar o Exame Nacional de Cursos, além da Lei de Diretrizes e Bases no ano seguinte.

Ou seja, podemos observar a inter-relação do processo de internacionalização da educação superior com as transformações ocorridas no âmbito do capitalismo mundial. $\mathrm{Na}$ conjuntura estabelecida, especialmente a partir dos anos de 1990, ganha força o debate sobre a mudança de categoria da educação, colocando, desde então, a Organização Mundial do Comércio (OMC) e o Banco Mundial no centro dessa disputa política.

\section{A configuração no Brasil}

2 A conjuntura política de 1995 a 2015, no Brasil, permite-nos observar a reconfiguração do campo da educação superior. Aspecto interessante desse processo é o fortalecimento do produtivismo pautado na lógica do capitalismo acadêmico, em que a busca por publicações se constitui em importante moeda para progressões nos quadros de carreira das universidades públicas. Com isso, cria-se um comportamento de circulismo em periódicos, pois o que se tem em meta é o volume da produção, um ranking das publicações que constam no currículo Lattes. As relações daí geradas se pautam em uma espécie de "clientelismo" acadêmico, cujo vínculo de dependência que se estabelece encontra-se articulado ao domínio dos espaços institucionais.

3 Outro aspecto do valor sobre as universidades públicas, pode-se assim dizer, foi o reconhecimento pelo Supremo Tribunal Federal (STF), em abril de 2017, de que essas instituições estavam autorizadas a cobrar taxas e mensalidades em cursos de pósgraduação lato sensu. Com isso, abre-se o espaço para se alastrar cursos pagos em instituições públicas. Isto é, afirma-se a tendência de privatização da universidade pública.

Ao mesmo tempo, no que diz respeito ao setor privado, observa-se um forte incentivo para sua expansão com o gradativo aumento de financiamento público. Nesse sentido, é interessante a posição da Confederação Nacional dos Trabalhadores em Estabelecimentos de Ensino (CONTEE) que se mostrou crítica em relação à política do MEC para as universidades privadas. Em audiência no Senado, no dia 10 de julho de 2013, denunciou a formação de oligopólios no setor que passaram a concentrar $74 \%$ das matrículas no Brasil. Essa situação foi gerada, além dos fluxos internacionais e das fusões de empresas, também 
a partir do incentivo do Fundo de Financiamento Estudantil (FIES), criado em 1999, proporcionando a expansão do ensino superior privado em 150\%, somente entre 2000 e 2011(Disponível em: http://contee.org.br/contee/index.php/2013/07/contee-denunciaformacao-de-oligopolio-no-ensino-superior-durante-audiencia-no-senado/ \#.VgxlPhG5eP8. Acesso em: out. 2015).

Ao mesmo tempo que serve para viabilizar o ingresso de estudantes de classe popular na universidade, igualmente atende aos interesses da classe empresarial. Nesse sentido, a transferência dos recursos para essas universidades, através do Fies, atinge somas significativas.

O Fies foi turbinado pelo atual governo em 2010, quando passou a cobrar juros mais baixos dos alunos e flexibilizou regras de pagamento e de exigência de fiador. Nos seus primeiros quatro anos de existência, teve um aumento de $735 \%$ e o custo do governo com o programa foi multiplicado em 17 vezes nos últimos cinco anos, de R\$ 810 milhões em 2010 para R\$13,75 bilhões, em 2014.

No entanto, as matrículas nos quatro anos antes do Fies cresceram em $21,9 \%$. Já nos quatro anos após a criação do programa, a variação foi menor: 13,4\%. Os melhores dados verificados após a mudança são o de número de ingressantes, que cresceu significativamente. Isso, porém, ainda não se traduziu em mais alunos se formando. Pelo contrário, o número de concluintes do setor ficou praticamente estagnado desde 2010, uma sinalização de que muitos alunos estão entrando, mas poucos se formando. Além de ainda não estar trazendo os resultados esperados, uma das dúvidas sobre o Fies é se ele será viável financeiramente (OGLOBO.COM, 27/02/2015. Acesso em: out. 2015).

O Banco Mundial, pela importância política e econômica que tem no continente, nos últimos tempos passou a buscar maior ingerência no campo da educação. Objetivando definir parâmetros educacionais para a América Latina e Caribe, o que inclui o Brasil, afirma em seu relatório de 2014, que

O maior desafio para elevar a qualidade dos professores não é fiscal nem técnico, mas político, porque os sindicatos dos professores em todos os países da América Latina são grandes e politicamente ativos; entretanto, um número crescente de casos bem-sucedidos de reformas está produzindo lições que podem ajudar outros países. (BRUNS/LUQUE, 2014. p. 26.)

107 Ou seja, o órgão define como essencial a desarticulação do movimento sindical docente, além de responsabilizar o movimento pela baixa qualidade da educação. Os sindicatos, para o Banco, se constituiriam em um entrave político às reformas de interesse da instituição, obviamente sob a perspectiva da mudança da categoria de direito para a de serviço. Essa orientação se opõe frontalmente, portanto, à participação da sociedade civil na definição das diretrizes das políticas públicas como mecanismo de consolidação da cidadania, colocando a instituição financeira em rota de colisão com os movimentos sociais e sindical.

Os pressupostos a seguir, apresentados por Barreto e Leher em uma análise sobre a materialidade do discurso do Banco Mundial, nos permitem analisar os sentidos circulantes nas publicações da agência e sua relação com os interesses em jogo:

a agência sabe o que é melhor para o mundo e usará seu poder político-econômico para ajustá-lo a essa formatação. $\mathrm{Na}$ assimetria que constitui suas relações com os Estados nacionais, especialmente os periféricos, estabelece as condicionalidades funcionais aos interesses geopolíticos (dos países centrais) e econômicos (de suas corporações e financeiras), persuadindo o conjunto da sociedade de que, supostamente não havendo alternativas, as ações impostas não configuram escolhas, mas soluções que emergem do encaminhamento correto dos 
problemas (BARRETO/LEHER, Roberto, 423-592, 2008, <http://www.scielo.br/ scielo.php?script=sci_arttext\& pid=S1413-24782008000300002>. p. 424. Acesso em: fev. 2012).

A linha política traçada pelo Banco não representa uma ação ainda a ser posta em prática. Na realidade, essa lógica vem sendo adotada e ganhando corpo desde os anos de 1990. Nesse sentido, cabe lembrar que a gradativa implementação e reformas das políticas educacionais, no Brasil, objetivando a permitir o avanço do capital privado sobre o campo da educação, não deixou de contar com o apoio do Estado.

110 Nesse caso, pode-se destacar o papel central ocupado pelo Estado no amparo à acumulação capitalista no país. Ou seja, a formulação da política para a educação superior tem sua origem no interesse do setor privado.

111 É sob essa perspectiva, conciliada com a afirmação da tendência à mercantilização da educação, que o art. $1^{\circ}$ do decreto $n^{\circ} 2.306$ (19/8/1997), portanto no governo FHC, permitiu que as entidades mantenedoras da educação superior privada se classificassem como de natureza civil e comercial, e quando fundações, passariam a ser regidas pelo Código Civil Brasileiro (art. 24). Dessa forma, se constituiriam como entidades comerciais.

Com base nesse dispositivo, passaram a ser classificadas como: entidade mantenedora de instituição sem finalidade lucrativa e entidade mantenedora de instituição particular, em sentido estrito, com finalidade lucrativa. As últimas, ainda que de natureza civil, quando mantidas e administradas por pessoa física, ficam submetidas ao regime da legislação mercantil no que diz respeito aos encargos fiscais, parafiscais e trabalhistas (SAMPAIO, 2011, p.31. (https:// www.revistaensinosuperior.gr.unicamp.br/artigos/o-setor-privado-de-ensinosuperior-no-brasil-continuidades-e-transformacoes).

112 A partir de então, com a abertura do caminho legal, as empresas de educação superior passaram a receber fortes incentivos à expansão. Nessas circunstâncias, em menos de uma década, o setor privado quase que triplicou sua participação no que diz respeito às matrículas no ensino superior, ao mesmo tempo em que passou a concentrar mais de $70 \%$ dessas matrículas, em 2008, conforme mostra a tabela abaixo.

Crescimento das matrículas de ensino superior por dependência administrativa: 2000 - 2008.

\begin{tabular}{|l|l|l|l|}
\hline Ano & Público & Privado & Total \\
\hline $\mathbf{2 0 0 0}$ & 780.166 & 1.807 .219 & 2.594 .245 \\
\hline $\mathbf{2 0 0 2}$ & 1.051 .655 & 2.428 .258 & 3.479 .913 \\
\hline $\mathbf{2 0 0 4}$ & 1.178 .328 & 2.985 .405 & 4.163 .733 \\
\hline $\mathbf{2 0 0 6}$ & 1.209 .304 & 3.467 .342 & 4.676 .646 \\
\hline $\mathbf{2 0 0 8}$ & 1.273 .965 & 3.806 .091 & 5.080 .056 \\
\hline
\end{tabular}

FONTE: MEC, SINOPSE ESTATÍSTICA DO ENSINO SUPERIOR.

113 Quando comparado com alguns países da América Latina, apenas para efeito de panorama, o percentual de alunos matriculados em Instituições de Ensino Superior (IES) públicas, em 2002, era: Argentina (87\%), Chile (31,5\%), México (66,3\%) e Uruguai $(86,2 \%)$ (NUNES/MARTIGNONI/RIBEIRO, 2004, p. 4). Observa-se que apenas o Chile, o principal laboratório do neoliberalismo no continente, se equipara ao Brasil no que se refere ao percentual de matrículas em IES públicas. 
114 Ou seja, nesses dois países há uma tendência de se privilegiar o setor privado da educação em detrimento do setor público, configurando-se uma conjuntura favorável ao entendimento da educação como serviço, o que denota a sua submissão à lógica do valor. Tal compreensão se torna mais explícita quando retomamos a informação do volume de recursos aportados e seu impacto no mapa das empresas privadas de educação superior. Um bom negócio, sem sombra de dúvidas, pois o custo do governo com o FIES teve um aumento de $735 \%$. Lembrando, ainda, que o montante da verba destinada ao programa "foi multiplicado em 17 vezes nos últimos cinco anos, de $\mathrm{R} \$ 810$ milhões em 2010 para $\mathrm{R} \$$ 13,75 bilhões, em 2014". Um forte atrativo para o capital de diversos ramos de atividades que passaram a compor os consórcios na educação superior, o que pode ser observado na tabela que se segue.

Despesa do Governo Federal em Educação em Pessoal e Encargos Sociais e em Grupos de Ações nas Demais GND: 2004 a 2014 (R\$ Bilhões de 2014)

\begin{tabular}{|c|c|c|c|c|}
\hline & 2004 & 2014 & $\begin{array}{c}\text { Participação } \\
\text { no total em } \\
2014\end{array}$ & $\begin{array}{l}\text { Var. Real } \\
2004-2014\end{array}$ \\
\hline Pessoal e encargos sociais & 11.890 & 29.723 & $32 \%$ & $150 \%$ \\
\hline $\begin{array}{l}\text { Concessão de financiamento estudantil-FIES e } \\
\text { antecessores }\end{array}$ & 1.138 & 13.769 & $15 \%$ & $1.110 \%$ \\
\hline Complementação da Uniào ao FUNDEF/FUNDEB & 832 & 10.862 & $12 \%$ & $1.205 \%$ \\
\hline $\begin{array}{l}\text { Funcionamento e Investim em inst. federais de ensino } \\
\text { superior }\end{array}$ & 2.546 & 8.790 & $9 \%$ & $245 \%$ \\
\hline Educação profissional e tecnológica & 436 & 7.127 & $8 \%$ & $1.533 \%$ \\
\hline Funcionamento e investimentos na educação básica & 2.402 & 6.999 & $7 \%$ & $191 \%$ \\
\hline $\begin{array}{l}\text { Bolsas de estudo no pais e no exterior - ensino } \\
\text { superior }\end{array}$ & 775 & 5.132 & $5 \%$ & $562 \%$ \\
\hline Apoio à alimentação escolar na educação básica & 1.740 & 3.702 & $4 \%$ & $113 \%$ \\
\hline Dinheiro direto na escola para a educação bảsica & 594 & 2.119 & $2 \%$ & $257 \%$ \\
\hline Apoio ao transporte escolar na educação básica & 444 & 977 & $1 \%$ & $120 \%$ \\
\hline Exames, avaliaçōes, estatisticas e censos & 192 & 815 & $1 \%$ & $325 \%$ \\
\hline Outros & 1.464 & 4.185 & $4 \%$ & $186 \%$ \\
\hline Total & 24.453 & 94.201 & $100 \%$ & $285 \%$ \\
\hline Total sem FIES & 23.315 & 80.431 & & $245 \%$ \\
\hline
\end{tabular}

Fonte : Sistema Siga Brasil e IBGE. Nota : Deflator IPCA Junho a Julho.

116 Ao observarmos a tabela, constatamos que, além da elevação dos aportes de recursos, o Fies, em 2014, passou a corresponder à metade das verbas destinadas à educação superior. Nesse sentido, Roberto Leher destaca que

[...] há mudanças no que diz respeito a mercantilização da educação, diferente do que acontecia até 2006 no Brasil. Os novos organizadores dessa mercantilização são organizações de natureza financeira, particularmente os chamados fundos de investimento.

Como o próprio nome diz, os fundos de investimentos são fundos constituídos por vários investidores, grande parte estrangeira, como fundos de pensão, trabalhadores da GM, bancos, etc., que apostam num determinado fundo, e esse fundo vai fazer negócios em diversos países.

Em geral, os fundos fazem fusões, como é o caso da Sadia e Perdigão no Brasil. Mas é o mesmo grupo que também adquire faculdades e organizações educacionais com o objetivo de constituir monopólios.

Esse processo levou a Kroton e a Anhanguera - fundo Advent e Pátria - a constituírem, no Brasil, a maior empresa educacional do mundo, um conglomerado que hoje já possui mais de 1,2 milhão de estudantes, mais do que todas as universidades federais juntas (LEHER, 2015). 
117 Nota-se que o avanço da lógica do valor implicou na concepção da educação como serviço e, portanto, como mercadoria com aportes de verbas públicas. O cenário que se configurou permitiu que apenas cinco fundos de pensão detivessem "cerca de $40 \%$ das matrículas da educação superior brasileira, e três fundos [...] quase $60 \%$ da educação à distância no Brasil" (LEHER, 2015).

Essa conjuntura também é possibilitada, no Brasil, pelo simbolismo do diploma universitário para a classe popular. Sua articulação com os interesses de negócio do empresariado criou um campo fértil para o lucro. Definiam-se assim o mercado, entendido como de competência do capital, as fronteiras e os sujeitos do diálogo sobre a política de educação superior.

119 Nessa perspectiva, a produção de valor a que o campo da educação se encontra submetido desde então, em especial a educação superior, passa a buscar, invariavelmente, formas flexíveis de organização, bem como o investimento em novas tecnologias se constitui em exigência fundamental. Dessa forma, o distanciamento do trabalho vivo (trabalhador) da produção direta das mercadorias específicas desse campo tem levado à organização e expansão da educação a distância (EaD), implicando, diante disso, na redução drástica do número de trabalhadores em atividade.

O ritmo de expansão dessa modalidade de ensino demonstra o grau de interesse dos empresários:

A educação a distância cresce em ritmo mais acelerado que a presencial. Os dados do último Censo da Educação Superior, de 2015, mostram que enquanto o ensino presencial teve um crescimento de 2,3\% nas matrículas em 2015 em relação a 2014, o ensino a distância teve expansão de 3,9\%. Com isso, a educação a distância atinge a participação de $17,4 \%$ do total de matrículas da educação superior. A rede privada concentra a maior parte das matrículas na modalidade (1.265.359) o que representa 90,8\% do total de 1.393 .752 registradas em 2015. (http://agenciabrasil.ebc.com.br/ educacao/noticia/2017-05/decreto-define-criterios-para-que-escolas-tenhamensino-distancia. Acessado em 10/04/2018).

Podemos observar, com isso, que o avanço da automação tem implicado na adoção de forma flexível de gestão pautado pela lógica do valor que estabelece, por sua vez, o critério de organização do campo da educação superior no Brasil. Assim sendo, há de se considerar como um de seus aspectos e impactos a expansão da EaD na conformação de suas relações internas, pois, retornando à Marx: “o capital não é uma coisa, mas uma relação social entre pessoas, efetivada através de coisas".

Nesse sentido, a formação do trabalhador que possui/possuirá o ensino superior em EaD está/estará impactada por tal lógica. Nela, um número cada vez maior de profissionais é formado através de materiais didáticos tanto padronizados quanto anualmente reproduzidos em sua essência e em série.

Estes estão, desse modo, distantes, na graduação, da pluralidade e diversidade de cursos que a educação presencial proporciona, onde cada docente organiza sua disciplina de forma ideológica e culturalmente diversa para pequenos grupos de estudantes. Na forma presencial, o objetivo é, quase sempre, o de mediar os debates e pluralidades de culturas e visões de mundo, além de profundidades de reflexões.

Embora na EaD os estudantes estejam sob um discursos da democratização da educação pela ampliação do acesso ao ensino, tendo em vista a redução dos custos, as possibilidades de uma formação plural lhes são tiradas. Ou seja, na solidão de sua tela ele tem acesso a materiais padronizados e perde-se a tensão e riqueza dos debates presenciais, já que a 
escrita nos "fóruns de discussão de EaD" pode ser mediada pelo autocontrole do que se escreve, dado que ficará registrado por todos e o professor poderá usar esse (registro) como avaliação.

Outra necessária reflexão sobre a padronização dos materiais didáticos está diretamente relacionada às avaliações de larga escala. Neste caso, para o Exame Nacional de Desempenho do Estudante (Enade), quanto maior o número de estudantes sendo formados através de discursos e conceitos padronizados maior serão as respostas muito perecidas e, consequentemente, notas padronizadas. Estariam tais graduandos/graduados mais preparados, reflexivos e críticos ou estarão reproduzindo formatações que eliminam a diversidade humana, estudantil, social e econômica?

"Sozinho" desde a sua formação, terá um dia este futuro profissional desenvolvido a noção de coletividade no processo de trabalho? Isto é, seria ele, ainda, capaz de consciência crítica de classe, ou estaríamos assistindo, invariavelmente, a queda do seu nível intelectual? Diante dessa situação, o futuro trabalhador estará fadado à passividade diante da ampliação da jornada ou do aumento da intensidade de trabalho?

Longe de ter a pretensão de responder tais questões, o texto objetivou provocar o debate sobre capitalismo contemporâneo, tendo por base a teoria do valor e seu impacto sobre a educação. Para tal, a perspectiva histórica se constituiu em recurso metodológico para o estabelecimento desse diálogo, bem como na construção do cenário que desemboca na formação dos futuros profissionais.

\section{BIBLIOGRAFIA}

AGUILAR, Hugo Aboites. Tratado de Libre Comercio y educación superior. El caso de México, un antecedente para América Latina. In: Educativos, vol.29, no.118, México ene. 2007.

BARRETO, Raquel Goulart; LEHER, Roberto. Do discurso e das condicionalidades do Banco Mundial, a educação superior "emerge" terciária. Revista Brasileira de Educação, v. 13 n. 39 p. 423-592, set./dez. 2008. Disponível em: <http://www.scielo.br/scielo.php?script=sci_arttext\& pid=S1413-24782008000300002>. p. 424. Acesso em: fev. 2012.

BOTTOMORE,Tom. Dicionário do Pensamento Marxista. Rio de Janeiro: Zahar, 2012.

BOURDIEU, Pierre. Revista Brasileira de Ciência Política, no 5. Brasília, janeiro-julho de 2011, pp. 193-216.

BRUNS, Barbara e LUQUE, Javier. Professores Excelentes - Como melhorar a aprendizagem dos estudantes na América Latina e no Caribe. (Fóruns sobre Desenvolvimento na América Latina) - GRUPO BANCO MUNDIAL, Washington, 2014. p. 26.

Dicionário Gramsciano. São Paulo: Boitempo, 2017. Disponível em: http://contee.org.br/ contee/index.php/2013/07/contee-denuncia-formacao-de-oligopolio-no-ensino-superiordurante-audiencia-no-senado/\#.VgxlPhG5eP8 Acesso em: out. 2015.

FÁVERO, Maria de Lourdes de Albuquerque.. http://23reuniao.anped.org.br/textos/1118t.PDF. Acessado em 03/07/2018. 
FERNANDES, Florestan. A Revolução Burguesa no Brasil. Rio de Janeiro: Zahar, 1976.

FRIGOTTO, Gaudêncio. A Produtividade da escola improdutiva: um (re)exame das relações entre educação e estrutura econômico-social capitalista. São Paulo: Cortez, 2010.

GIOVANNI, Arrighi. A ilusão do desenvolvimento. Petrópolis: Vozes, 1997.

GRAMSCI, A. Os intelectuais e a organização da cultura. Rio de Janeiro: Civilização Brasileira, 1995.

Cadernos do Cárcere. Rio de Janeiro: Civilização Brasileira, v. 1, 2004.

GUILE, David. O que distingue a economia do conhecimento? Implicações para a educação. Cadernos de Pesquisa, v. 38, n. 135, p. 611-636, set./dez. 2008.

HALL, Stuart. A identidade cultural na pós-modernidade. $9^{\mathrm{a}}$ Ed., Rio de Janeiro: DP \& A, 2004.

HARVEY, David. Condição Pós-Moderna. São Paulo: Loyola, 14ª ed., 2005. p.135.

Neoliberalismo, projeto político. Disponível em : outraspalavras.net/capa/

neoliberalismo-projeto-politico/

http://agenciabrasil.ebc.com.br/educacao/noticia/2017-04/menos-de-20-dos-trabalhadores-

brasileiros-sao-sindicalizados. Acesso em outubro de 2017.

http://agenciabrasil.ebc.com.br/educacao/noticia/2017-05/decreto-define-criterios-para-queescolas-tenham-ensino-distancia (acessado em 10/04/2018).

https://www.unas.org.br/single-post/2017/01/19/Desigualdade-no-Brasil. Acesso em outubro de 2017.

JAMENSON, Fredric. Pós-modernidade e sociedade consumo. Novos Estudos CEBRAP, São Paulo, n. ${ }^{\circ}$ 12, pp. 16-26, jun. 1985.

LEHER, Roberto. Grandes grupos econômicos estão ditando a formação de crianças e jovens brasileiros. In, Brasil de Fato, 01/07/2015.

LIPPI OLIVEIRA, L. (coord.). Elite intelectual e debate político nos anos 30. Rio de Janeiro: FGV, 1980.

LUKÁCS, György. Prolegômenos para uma ontologia do ser social. São Paulo, Boitempo, 2010.

MARX, K. \& ENGELS, F. Manifesto do Partido Comunista. Petrópolis, Vozes, 6롤., 1996.

MARX, Karl. o Capital. Crítica da Economia Política. Livro I, vol. II. Rio de Janeiro: Civilização Brasileira, 1980.

. Trabalho Assalariado e Capital. <https://www.marxists.org/portugues/ marx/1849/04/05.htm>. Acesso em outubro/2017.

. Salário, Preço e Lucro. https://www.marxists.org/portugues/marx/1865/salario/ cap03.htm\#i14. Acesso em outubro/2017

. Para a Crítica da Economia Política. https://www.marxists.org/portugues/ marx/1859/01/prefacio.htm. Acesso em outubro de 2017 o Capital. Livro I - capítulo VI. São Paulo: Livraria Editora Ciências Humanas Ltda. 1978.

MENDONÇA, Ana Waleska P.C. A Universidade no Brasil. Revista Brasileira de Educação. Mai/ Jun/Jul/Ago, 2000, no 14, p. 131-194.

MÉSZÁROS, István. O poder da ideologia. São Paulo, Boitempo, 2004. p.65. 
NUNES, Edson / MARTIGNONI, Enrico / RIBEIRO, Leandro Molhano. Economia Política e Regulação da Educação Superior no Brasil. In, Observatório Universitário. Documento de Trabalho nº. 41, dezembro de 2004.

OGLOBO.COM, 27/02/2015. Acesso em: out. 2015.

POSTONE, Moishe. Tempo, trabalho e dominação social. São Paulo: Boitempo, 2014.

SAMPAIO, Helena. Evolução do ensino superior brasileiro, 1808 - 1990. Núcleo de Pesquisas sobre Ensino Superior da Universidade de São Paulo, 1991.

SAMPAIO, Helena. O setor privado de ensino superior no Brasil: continuidades e transformações. In, Revista Ensino Superior, Unicamp, 2011, p.31. (https://

www.revistaensinosuperior.gr.unicamp.br/artigos/o-setor-privado-de-ensino-superior-nobrasil-continuidades-e-transformacoes).

SANTOS, Theotônio. A teoria da dependência: balanço e perspectivas. Florianópolis: Insular, 2015.

SAUL, Renato P.. As raízes renegadas da teoria do capital humano. Sociologias, Porto Alegre, ano 6, no 12 , jul/dez 2004, p. 230-273.

SEGRERA, Francisco López. Tendencias de la educación superior en el mundo y en América Latina y el Caribe. In: Avaliação (Campinas), vol.13, no.2, Sorocaba - June 2008. (http://

dx.doi.org/10.1590/S1414-40772008000200003). Acessado em 18/11/2015.

SILVA, Ludovico. A Mais-valia ideológica. Florianópolis, Insular, 2013. p. 58.SERAFIM, Milena Pavan. O processo de mercantilização das Instituições de educação superior: um panorama do debate nos EUA,na Europa e na América Latina. In: Avaliação, Campinas; Sorocaba, São Paulo, v. 16, n. 2, p. 241-265, jul. 2011.

WIELEWICKI, Hamilton de Godoy/OLIVEIRA, Marlize Rubin. Internacionalização da educação superior: Processo de Bolonha. In: Ensaio: aval. pol. públ. Educ., Rio de Janeiro, v. 18, n. 67, p. 215-234, abr./jun. 2010.

ZIZEK, Slavoj. Violência: seis reflexões laterais. São Paulo: Boitempo, 2014. p.74.

\section{NOTAS}

1. "Para Marx, o valor de uma MERCADORIA expressa a forma histórica particular do caráter social do trabalho sob o capitalismo, enquanto dispêndio de FORÇA DE TRABALHO social. O valor não é uma relação técnica, mas uma relação social entre pessoas que assume uma forma material específica sob o capitalismo, e portanto aparece como uma propriedade dessa forma. Isso sugere, em primeiro lugar, que a generalização do trabalho humano como mercadoria é específica ao capitalismo e que o valor, como conceito de análise, é igualmente específico ao capitalismo. Em segundo lugar, sugere que o valor não é apenas um conceito com uma existência puramente mental, mas que ele tem existência real, constituindo as relações de valor a forma particular assumida pelas relações sociais capitalistas." (BOTTOMORE,Tom. Dicionário do Pensamento Marxista. Rio de Janeiro: Zahar, 2012. p.622).

2. Campo "é um microcosmo, isto é, um pequeno mundo social relativamente autônomo no interior do grande mundo social. Nele se encontrará um grande número de propriedades, relações, ações e processos que se encontram no mundo global, mas esses processos, esses fenômenos, se revestem aí de uma forma particular. É isso o que está contido na noção de autonomia: um campo é um microcosmo autônomo no interior do macrocosmo social." 
(BOURDIEU, Pierre. Revista Brasileira de Ciência Política, nº 5. Brasília, janeiro-julho de 2011, pp. 193-216. p. 195).

3. Trabalho abstrato: "qualquer ato de trabalho pode ser considerado separadamente de suas características específicas, simplesmente como dispêndio de força de trabalho humana, 'o trabalho humano puro e simples, o dispêndio do trabalho humano em geral'. 0 dispêndio de trabalho humano considerado sob esse aspecto cria valor e é chamado de trabalho abstrato." (BOTTOMORE, Tom. Dicionário do pensamento marxista. Rio de Janeiro: Jorge Zahar,1988. p. 383). 4. Para Gramsci, revolução passiva é quando "a base material da hegemonia é constituída mediante reformas ou concessões graças às quais mantém-se a liderança de uma classe, mas pelas quais outras classes têm certas exigências atendidas." (BOTTOMORE, p. 284).

5. Do total de 94,4 milhões de trabalhadores no Brasil, 18,4 milhões são sindicalizados, o que corresponde a $19,5 \%$.

http://agenciabrasil.ebc.com.br/educacao/noticia/2017-04/menos-de-20-dos-trabalhadoresbrasileiros-sao-sindicalizados

) Acesso em outubro de 2017

6. “Concepção de mundo é expressão usada por Gramsci do mesmo modo que ideologia, mas num sentido ainda mais amplo, para indicar o terreno conectivo sobre o qual surgem graus diversos de elaboração das capacidades do sujeito de interpretar a realidade" (Dicionário Gramsciano. São Paulo: Boitempo, 2017. p.135).

7. Sobre a formação da universidade no Brasil, os grupos políticos-intelectuais e a interferência do Estado nesse processo, ver o artigo de MENDONÇA, Ana Waleska P.C. A Universidade no Brasil. Revista Brasileira de Educação. Mai/Jun/Jul/Ago, 2000, no 14, p. 131-194.

8. O Estatuto do professor catedrático o define como o primeiro na hierarquia do corpo docente. "Quanto aos demais professores, auxiliares dos catedráticos, fossem eles 'chefes de clínica', 'chefes de laboratórios', 'assistentes' ou 'auxiliares de ensino' deveriam ser de confiança do respectivo catedrático, por ele escolhido e cuja permanência no cargo, dele, quase sempre dependia [...] Essa questão se torna mais delicada por ser a escolha dos assistentes e auxiliares, como assinalado antes, resultado quase exclusivo do arbítrio do catedrático, em decisões às vezes tendenciosas e eivadas de autoritarismo. A ideia de cátedra contida no Estatuto das Universidades Brasileiras ganha força com as constituições de 1934 e 1946. Na primeira, são estabelecidos os seguintes requisitos: garantia da liberdade de cátedra; vedada a dispensa do concurso de títulos e provas no provimento dos cargos do magistério oficial; garantia aos professores nomeados por concurso para os institutos oficiais da vitaliciedade e da inamovibilidade nos cargos. [A] Carta Magna de 1946 consagra três pressupostos, à época considerados fundamentais. São eles: provimento das cátedras por concurso de títulos e provas, liberdade de ensino e vitaliciedade. (FÁVERO, Maria de Lourdes de Albuquerque. Da Cátedra Universitária ao Departamento: subsídios para discussão, pp. 3 e 4 . http://23reuniao.anped.org.br/textos/1118t.PDF - Acessado em 03/07/2018).

\section{RESUMOS}

Este artigo objetiva analisar o deslocamento do princípio norteador da educação superior no Brasil na passagem para o século XXI. Entendemos que ocorre uma reordenação e reconfiguração de suas relações a partir do estabelecimento da hegemonia capitalista de orientação neoliberal em fins do século XX. Entendendo que o capital exerce o poder de condicionar e articular as 
relações sociais no âmbito da economia, da cultura, da política e da ideologia, este poder submete tais relações, portanto, à lógica do capital. É ele quem as conforma para moldá-las e transformálas permanentemente. Nesse sentido, o capital tencionando e conformando as relações sociais submetendo-as à lógica do valor. Tensionamentos e conformações impulsionadas e favorecidas pela introdução de novas tecnologias e/ou novas formas de organização, além de novas demandas econômicas e sociais. Dessa forma, o capital é entendido como relação social de produção e de consumo, isto é, articulando as condições de produção estrutural com a subjetividade por ela gerada. Por isso, interpelar as transformações vivenciadas em espaços de manipulação e produção de subjetividades possibilita-nos observar as novas conformações das relações que neles se estabelecem. Por isso, o campo da educação ganha centralidade nesse debate. Não somente por sua responsabilidade na formação intelectual dos indivíduos, mas também pela reconfiguração de suas relações a partir do avanço da lógica do valor. Para tal, privilegiaremos o setor privado do ensino superior por ser este o mais sensível a essas transformações, bem como, enquanto empresas, se constituem em sujeitos de pressão para a expansão das novas configurações de relações sociais. Essa opção decorre do fato de entendermos que está em curso a reconfiguração do papel desempenhado pelo ensino superior no Brasil. Reconfiguração que tem nas transformações vivenciadas nas relações capitalistas, em nível mundial e nacional, seu motor.

This paper aims to analyze the change in the higher education guiding principle in Brazil before the 21st century. It is observed that a reorganization and reconfiguration of relations take place from the rise of the neoliberal oriented capitalist hegemony at the end of the 20th century. From the standpoint that capital has the power to regulate and articulate social relations in economy, culture, politics and ideology, this power subjects such relations to a capitalist the logic. Capital is what molds and transforms these relations permanently. In this sense, capital designs social relations by submitting them to the logic of value. Tensions and conformations are favored by the introduction of new technologies and/or new ways of organization as well as new economic and social demands. In this way, capital is understood as a social relation of production and consumption, that is, it articulates the structural production conditions with the subjectivity it creates. For this reason, questioning the transformations experienced in spaces of manipulation and production of subjectivities allow us to observe new conformations of the relations that are established in these spaces. That is why education is central to this debate. Not only for its responsibility in forming individuals intellectually, but also for reconfiguring their relations as the logic of value advances in importance. To this end, we favor the higher education private sector because it is the most sensitive to these transformations, because as companies, they pressure for the expansion of social relations new configurations. This option comes from the fact that we see that the role of higher education in Brazil is being reconfigured. Reconfiguration that is driven by transformations experienced in capitalist relations both in global and national level.

Este artículo analiza el desplazamiento del principio orientador de la educación superior en Brasil hacia el siglo XXI. Existe una reordenación y reconfiguración de sus relaciones a partir del establecimiento de la hegemonía capitalista de orientación neoliberal a fines del siglo XX. Entendiendo que el capital ejerce el poder de condicionar y articular las relaciones sociales en el ámbito de la economía, de la cultura, de la política y de la ideología, este poder somete tales relaciones a la lógica del capital. Es pues el capital, quien las conforma para moldearlas y transformarlas permanentemente. En ese sentido, el capital pretendiendo y conformando las relaciones sociales sometiéndolas a la lógica del valor. Tendencias y conformaciones impulsadas y favorecidas por la introducción de nuevas tecnologías y / o nuevas formas de organización, además de nuevas demandas económicas y sociales. De esta forma, el capital es entendido como relación social de producción y de consumo, es decir, articulando las condiciones de producción 
estructural con la subjetividad por ella generada. Por eso, interpelar las transformaciones vivenciadas en espacios de manipulación y producción de subjetividades nos posibilita observar las nuevas conformaciones de las relaciones que en ellos se establecen. Dado lo anterior, el campo de la educación gana centralidad en ese debate. No sólo por su responsabilidad en la formación intelectual de los individuos, sino también por la reconfiguración de sus relaciones a partir del avance de la lógica del valor. Para ello, nos enfocaremos en el sector privado de la enseñanza superior, por ser éste el más sensible a esas transformaciones, dado que, como empresas, se constituyen en sujetos de presión para la expansión de las nuevas configuraciones de las relaciones sociales. Esta opción, deriva del entendimiento que está en curso la reconfiguración del papel desempeñado por la enseñanza superior en Brasil. Reconfiguración cuyo motor yace en las transformaciones vivenciadas en las relaciones capitalistas, a nivel mundial y nacional.

Cet article tente d'analyser le déplacement de la ligne directrice de l'enseignement supérieur au Brésil, au tournant du XXIe siècle. Nous considérons qu'il y a un réagencement et une réorganisation des rapports qu'il établit, à partir de l'établissement d'une hégémonie capitaliste à tendance néolibérale, à la fin du XXe siècle.

Nous considérons que le capital exerce un pouvoir consistant à conditionner et à articuler les rapports sociaux, dans les domaines de l'économie, de la culture, de la politique et de l'idéologie et que ce pouvoir soumet donc ces rapports à la logique du capital. C'est lui qui les configure, pour les modeler et les rendre permanents.

Dans ce sens, le capital prescrit et conçoit les rapports sociaux en les soumettant à la logique de la valeur. Ces conceptions et ces configurations sont fomentées et favorisées par l'introduction de nouvelles technologies et/ou de nouvelles formes d'organisation, ainsi que par les nouveaux besoins économiques et sociaux.

Ainsi, le capital est envisagé comme un rapport social caractérisant la production et la consommation, c'est-à-dire en articulant les conditions qui régissent la production structurelle avec la subjectivité qu'elle génère. Par conséquent, le fait de questionner les transformations vécues dans des espaces qui renvoient à la manipulation et à la production de la subjectivité nous permet de repérer les nouvelles configurations des rapports qui s'établissent dans ces espaces.

C'est pourquoi le domaine de l'enseignement se place au cœur de ce débat. Non seulement parce qu'il est responsable de la formation intellectuelle des individus, mais aussi en raison de la reconfiguration des rapports qu'il établit, en fonction de la progression de la logique de la valeur. À ces fins, on privilégie le secteur de l'enseignement supérieur privé, car il est plus sensible à ces transformations et parce que les entreprises de ce secteur exercent une pression en vue de l'expansion des nouvelles configurations des rapports sociaux. Nous avons fait ce choix car nous avons constaté que le rôle que joue l'enseignement supérieur au Brésil est en cours de reconfiguration. Une reconfiguration qui trouve son moteur dans les transformations que connaissent les rapports capitalistes, au niveau mondial et au niveau national.

\section{ÍNDICE}

Mots-clés: capitalisme, enseignement, théorie de la valeur, néolibéralisme.

Keywords: capitalism, education, value theory, neoliberalism

Palavras-chave: capitalismo, educação, teoria do valor, neoliberalismo

Palabras claves: capitalismo, educación, teoría del valor, neoliberalismo 


\section{AUTORES}

HIRAN ROEDEL

Historiador e Doutor em Comunicação pela UFRJ

\section{ISA FERREIRA MARTINS}

Doutora em Educação pela UERJ e Mestre em Literatura pela UFF 